\title{
A tudománymüvelés és a tudományokban való jártasság mint emberi jog. Egy arkhimédészi pont azonosítása
}

\section{Z. KARVALICS LÁSZLÓ}

Hosszú út vezetett odáig, hogy a tudományok eredményeiből való részesedés mellett 2012-ben megjelent a tudománytermeléshez való hozzájárulás, a tudományos kutatásokban való részvétel jogának a követelése is. A tanulmány számos oldalról közelíti meg, miért van rendkívüli jelentösége a tudományképességnek és a részvételiségnek, hogyan függ mindez össze a tudományos müveltség új korszakával, miként nőhet ki ebből az „élethosszig tartó kutatás" gyakorlata, és hogy valójában nem jogokmeg-, hanem visszaszerzéséröl van szó.

Kulcsszavak: a tudományhoz való jog, tudományos műveltség, állampolgári tudomány, hálózati erőforrásszerzés, élethosszig tartó kutatás

\section{Science Making and Scientific Literacy as Human Rights. Identifying an Archimedean Point}

The content of the Right to Science is changing. After the Second World War it was defined as a right "to share in scientific advancement and its benefits.' Since 2012, it has started to widen to a more open interpretation: "opportunities for all to contribute to the scientific enterprise and freedom indispensable for scientific research". The paper provides considerations about the importance of scienceability and participative architectures, the new epoch of science literacy and the paradigm of lifelong research. Let alone it is not about acquiring new rights - but winning back a long-time existing role as people's science.

Keywords: the Right to Science (RtS), scientific literacy, citizen science, crowdsource, lifelong research 


\section{Bevezetés}

A „tudomány mint emberi jog” (human right to science, science, as a human right) ${ }^{1}$ terminus azóta igényli és provokálja a kifejezés tartalmának pontos értelmezését és megmagyarázását, amióta az Emberi Jogok Egyetemes Nyilatkozatának 27. cikkelye 1948. december 10-én az alábbi kanonizált formulában összegezte mindazt, amit a nemzetközi közösség azidőtájt erről fontosnak tartott elvárásként kijelenteni. ${ }^{2}$

Mindenkinek joga van szabadon részt venni közössége kulturális életében, élvezni a művészeteket, részesedni a tudományok elörehaladásából és eredményeinek hasznából. ${ }^{3}$

Az Egyesült Nemzetek Szervezete közel 20 év múlva, 1966-ban a közgyülésén elfogadott, a gazdasági, társadalmi és kulturális jogokat összefoglaló nemzetközi egyezménye ${ }^{4} 15$. cikkelyében megismételte, kicsit árnyalta és két szemponttal kiegészítette a háború utáni alapvetést.

Belátta, hogy ennek a jognak a realizálásához nélkülözhetetlennek tarthatunk bizonyos (tagállami) lépéseket - jelesül mindazt, amit a tudomány és a kultúra megörzése, fejlesztése és „szétteritése” (diffúziója) érdekében tehetnek. E lehetséges lépések egyik osztálya pedig a nemzetek közötti tudományos és kulturális kapcsolatok és együttmüködések (international contacts and co-operation) bátorítása és fejlesztése.

Akárhány nemzetközi szervezet alapdokumentum ismételte meg később, hogy szilárd formába öntse a tudománnyal mint emberi joggal kapcsolatos álláspontját, ${ }^{5}$ nem változtatott az 1948-as kiindulópontokon. Bowers ${ }^{6}$ helyesen érzékeli, hogy e cik-

1 A szakirodalomban leginkább a rövid „Right to Science” formula terjedt el, amely betűszó-

ként - RtS - is használatos. MANN, 2018.

2 A cikkely második pontja („Mindenkinek joga van valamennyi, általa alkotott tudományos, irodalmi és mủvészeti termékkel kapcsolatos erkölcsi és anyagi érdeke védelméhez") nem a tudománnyal, hanem a szellemi termékekkel kapcsolatos jogi diskurzus része. Hasonlóképpen hagyhatjuk figyelmen kívül a később és máshol definiált társjogot, amely a kutatói autonómiát, a tudományos kutatás szabadságát érinti: ez ugyanis a vélemény- és gondolatszabadsághoz tartozó speciális terület. Jellemző ugyanakkor, hogy például az Európai Unió 2000 decemberében elfogadott alapjogi chartája (Charter of Fundamental Rights) a maga 13. cikkelyében kizárólag ezt, a tudományos kutatás szabadságát erősíti meg, a másik vonatkozásra nem is tér ki. Ennek a kizárólag erre a szempontra szükülő látásmódnak érdekes példája a tudomány szabadságával foglalkozó nemzetközi szakmai közösség (World Congress for Freedom of Scientific Research) nyílt és csatlakozásra buzdító felhívása (Appeal for the Human Rights to Science, www.freedomofresearch.org/appello/), amely nem tesz mást, mint a tudomány (a tudománytámogatás és a tudomány-oktatás) fontosságát evangelizálja (a továbbiakban: Appeal).

3 „To share in scientific advancement and its benefits”. A közkeletű magyarra ültetések olykor helytelenül részvételt írnak részesedés helyett (erre még visszatérünk), és régiesen „jótéteményként” fordítják a benefit-et, Ez utóbbival kétszeresen torzítják el a cikkely értelmét: egyrészt belecsempészik a morális cselekvőt, aki „teszi” a jót, másrészt az akaratlagosságot (intencionalitást), ahol a hatás csak akkor érvényesül, ha az „tétetik” és kifejezetten a társadalom szolgálatában. Az alapszöveg hozzáférhető: www.un.org/en/universal-declaration-human-rights/(2019. 07. 01.)

4 International Covenant on Economic, Social, and Cultural Rights. Teljes szövege: www.ohchr.org/ en/professionalinterest/pages/cescr.aspx (2019. 07. 01.)

5 Áttekintésüket lásd itt: www.freedomofresearch.org/appello/ (2019. 07. 01.)

6 BOWERS 2018. 
kelyek szerzői láthatóan nem elsősorban arra kívánnak utalni, hogy miként tudják az individuumok különböző élethelyzeteikben és döntési szituációikban erőforrásként használni a maguk számára, amit a tudománytól kaphatnak. Sokkal inkább arra, hogy a tudomány a közjót minden egyes ember számára előmozdíthassa, függetlenül oktatási hátterüktől vagy egészségügyi helyzetüktől. A társadalom tagjai tehát úgy fogadják örömmel „a” tudománytól ${ }^{7}$ mindazt, amit „ad” és kínál, ahogy a művészek által létrehozott mủalkotásokat élvezik. Ez a megközelítés a tudományhoz való jogot az oktatáshoz, az információhoz vagy az élelemhez és az egészségügyi ellátáshoz való joghoz sodorja közel: részesedhessen mindenki a társadalom számára rendelkezésre álló erőforrásokból, közjószágokból. ${ }^{8}$ Ezzel egyrészt kimondatik a befogadóihaszonélvezői alapállás, másrészt végső kontextusként jelenik meg az egyenlöségiigazságossági-kölcsönösségi kiindulópont.

\section{A befogadói mivolt szemléleti hátteréhez}

Mancisidor ${ }^{9}$ az ENSZ-alapdokumentum szövegét kiformáló munkadokumentumokban (travaux préparatoires) nyomát találta annak, hogy egykor erős vitát váltott ki a passzivitást sugalló formula, és visszatérően felvetődött az aktív cselekvés kérdése, amit a részvételiség ideájának hangsúlyozásával kívántak ellensúlyozni. A vita végül a „share” ige értelmének kitágításával jutott nyugvópontra: a szöveg elfogadói akkor beleértették a participáció mozzanatát (amit a korabeli francia és spanyol fordításverzió tükröz is). ${ }^{10}$ Ebbe azonban nagy tévedés utólag visszavetíteni például napjaink állampolgári tudományának képzetét: leginkább a tudomány eredményeihez

7 A téma még átfogóbb tárgyalásakor annak is érdemes lehet néhány bekezdést szentelni, hogy miként is fordítható le praktikusan „a” tudomány. Soha nem önmagukban kerülnek tárgylemezre az „egyes” tudományok (tudományterületek, tudományszakok), de vajon hogyan ragadható meg a tudomány egésze? Hiszen abban, mint alrendszerben a tudományos intézmények, a tudományos óriásműszerek, a tudományos minősítés, a tudományos álláshelyek, a tudományos szakmai szervezetek, és sok minden más mellett természetesen a tudomány mindennemű produktuma is benne foglaltatik. Nyilvánvaló, hogy nem lehet emberi jogként megfogalmazni egy csillagászati összegbe kerülő érzékeny tudományos műszer használatba vételének lehetőségét, ahogy egy szakmai szervezethez való tartozás sem érvényesülhet szándék esetén automatikusan jogként. Ha ilyen szemmel nézünk a „tudományhoz való jog” irodalmára, akkor azt máris szigorúan a „tudományművelés eredményeinek megismeréséhez” való jogra kellene szűkíteni. Minderre lásd még „a tudomány egészének” kérdését önálló kötetben tárgyaló Zsolnai tudománypedagógiai alapvetését, amely a tudománytan és a kutatástan szétválasztásával nagy lépést tesz abba az irányba, hogy az absztrakt és a konkrét tartományokkal külön lehessen foglalkozni. Lásd: ZsolNAi 2005.

8 Belátható, hogy a jogok más osztályai egészen más kiindulópontokra épülnek. A szabadságjogok a belső tartalmak megoszthatóságával „a gondolatok közpiacára” vitelét támogatják, megint mások a társadalmi lét méltóságát célozzák vagy épp a környezet humanizálásának imperatívusza felé mutatnak (mint a fogyatékkal élők akadálymentesítése vagy a tiszta környezethez való jog).

9 MANCISIDOR 2015, 2.

10 Az azonban ezen viták során sem merült fel, hogy a tudomány eredményeinek „átszivárgása” a mindennapi életbe, amelynek során kedvező módon sikerül megváltoztatni annak bizonyos paramétereit, sokkal bonyolultabb és összetettebb kölcsönviszonyban és számos kifürkészhetetlen csatornán megy végbe, mint amit a részesítés-részesülés enyhén paternalista hangulatú nyelvi szerkezete sugall. 
való hozzáférést (access), és nem az eredmények létrehozásában játszott szerepet értettek alatta. Aktív jelenlétet a tudományos ismeretterjesztésben mint mozgalomban - amely a tudomány hasznaiból való részesedés kétségkívül magasabb foka - de ugyanúgy puszta befogadás. S végül a tudományos kutatások orientációjára való képességet - egyfajta megrendelői szerep érvényesülését tehát, a tudománypolitikára való hatásgyakorlás lehetőségét. ${ }^{11}$ Beleszólást abba, hogy milyen (etikus) felhasználást támogassanak a fejlesztések, $\mathrm{s}$ ennek révén milyen majdani eredményből részesedhessenek a polgárok.

Mindemögött az a szemléleti alapállás húzódik meg, hogy a tudósoknak a munkamegosztás részeként hivatásrenddé alakult serege az, ${ }^{12}$ amelyik a tudományos eredményeket elóállítja, az ipar, a gazdaság meg a társadalom pedig „birtokba veszi” azokat. És ma, amikor a tudomány alrendszereiben dolgozó kb. 8 millió tudós még mindig csak az össznépesség 0,1\%-át teszi ki, jól belátható, miféle matematika és világkép munkál az egyszerü képlet mögött: egy parányi, szakosított közösség állítja elő a tudást, amelyet aztán a világ többi része „alkalmaz”.13 Amikor a hangsúly a tudományos tudáshoz való univerzális hozzáférés (universal access) követelményére, a 2018. novemberi World Science Day rendezvények kiemelt témájára esik, ${ }^{14}$ azzal egyetlen centimétert sem mozdultunk el ettől a befogadói pozíciótól. Amikor a 2018 novemberében Buenos Airesben megszervezett UNESCO szakértői tanácskozás a tudományhoz való jog egységes koncepcióját sürgeti, ${ }^{15}$ de eközben a tudomány elvesző presztízse a kiindulópontja, ugyanebben a cipőben jár: a tudományos közösség érdekében emel szót, hogy „küldetését” teljesíthesse.

S valójában ugyanez a logika teljesedik ki a tudományok iskolai oktatásának filozófiájában és gyakorlatában is. A „tudományoktatás” (science education) a rendezett és tanulható tudássá lefordított diszciplináris ismeretcsomagok átadásának és befogadásának színtereként tekint az iskolára. A tankönyvíró és a tanár a tudomány

11 Ennek alesetének tekinthetjük a tudomány lehetséges kártékony következményeivel szembeni védelemhez való jogot, amit egy 2009-es, Velencében rendezett szakértői tanácskozáson Donders formulázott. DONDERs 2009, 8.

12 Jegyezzük meg: maga a tudós (scientist) elnevezés, mint a tudománnyal hivatásszerűen foglalkozó személy is csak 1833-ban született meg, egy egyházi személynek, William Whewellnek köszönhetően.

13 Ez húzódik meg amögött is, hogy a tudomány mint emberi jog diskurzus mai napig a kis számú tudós jogaira fejnehéz. Ha rápillantunk a két elődszervezet (International Council for Science - ICSU, és az International Social Science Council - ISSC) összevonásával létrehozott nem-kormányzati világszervezet (The International Science Council - ISC) alapdokumentumaira, azt látjuk, hogy ezekben minden létező találkozási pontot azonosítanak, ahogyan tudomány és emberi jogok metszhetik egymást, de ezeket minden alakváltozatában a tudomány kiemelt fontosságának és társadalmi szerepének hangsúlyozására használják. Hogy egyszerủ tudománymarketinggé silányítják az emberi jogi keretet, abban nincs semmi meglepő: hiszen közel félszáz nemzetközi és 140 nemzeti és regionális tudományszakmai szervezet, szövetség alkotja a tagságot. Lásd: https://council.science/ (2019. 07. 01.)

14 Chapman-Wyndham 2013.

15 Science as a human right: the need of a unified concept. Elérhető: https://en.unesco.org/news/ science-human-right-need-unified-concept (2019. 07. 01.) 
és a pedagógia szövetségét valósítja meg, amennyiben a közösen elfogadottnak tekintett vagy annak vélt tudományos ismereteket a didaktikailag legmegfelelőbb módon kívánják közvetíteni a felnövekvő nemzedékek számára (akinek legnagyobb része, 99,9\%-a nem lesz tudós). A diák befogadó, a meglévő ismereteket a tanulói munkával jól-rosszul újraépíti magában. Amikor a legkorszerűbb pedagógia és tudománynépszerűsítő irányzatok felfedező tanulásról (discovery learning), vagy annak továbbfejlesztett változatáról, a kutatásalapú tanulásról (Inquiry-based Learning - IBL) beszélnek, ${ }^{16}$ nem lépnek túl ezen a szemléleti kiindulóponton. Pusztán annyi történik, hogy nem direkt átadással, hanem közvetett módon válik befogadóvá, meglévő tudások reprodukálójává a diák. Azzal, hogy maga jut el a már egyszer megteremtett tudáshoz, kreatívan megkonstruálva azt, részvétele kétségkívül aktívabb a folyamatban. Ám annak eredménye mégis ugyanaz, mint az idejétmúlt, bornírt, reproduktív tudásszerzést erőltető gyakorlat, amely tölcsérrel tölt a gyermeki fejbe olyan ismereteket, amelyek létjogosultságát és konstrukcióját a tudomány szereplőin kívül szakmódszertani, ideológiai és politikai dimenziók is befolyásolják.

\section{Az egyenlőségi-igazságossági-kölcsönösségi szempont hátteréhez}

Mann ${ }^{17}$ a tudományhoz való joggal foglalkozó több mint félszáz tanulmány ${ }^{18}$ tartalomelemzését elvégezve azt találta, hogy egyetlen szempont szerepel valamennyi szövegben: a hozzáférés a tudományos eredményekhez és innovációkhoz (akármilyen formában, például oktatási anyag, egészségügyi szolgáltatás, könyv, újságcikk, szabadalom, gének és biológiai anyagok).

Mint láttuk, ez a befogadási aspektusnak is fontos szempontja volt: amihez nincs hozzáférés, annak hasznából nem tudunk részesülni. Ám jóval többről is szó van amiatt, hogy a tudományos eredményekhez való hozzáférés joga rendre ütközik a szellemi tulajdonjoggal. A hozzáférés így puszta anyagi kérdéssé válik, és mindenkit hátrányosan érint, aki a jövedelmi szakadék árnyékos oldalán helyezkedik el. Ezzel pedig egy olyan konfliktuszóna nyílik meg, amelynek friss fejleményei jól ismertek: az egyik oldalról a tudományos eredményeket közlő folyóiratok előfizetési díjaival szemben szerveződik ellenállás, a másik oldalról hatalmas online könyv- és folyóirat-adatbázisok épülnek, illegálisan, ahonnan ingyenesen letölthetővé válnak a jogvédett tartalmak is. (Más kérdés, hogy ez nem az általában vett „társadalmak” problémája, hanem a szegényebb országok tudósaié - ám az ő korlátozott hozzáférésük és kevésbé hatékony

16 NAgY-NagY 2016.

17 MANN 2018.

18 A RtS diskurzusa nem mondható kiterjedtnek, az ebbe a tárgykörbe sorolható publikációk száma csekély. Mégis, 2015-ben a baszkföldi Getxo városában önálló kutatóintézet jött létre jött létre (International Institute for the Human Right to Science). A szervezet honlapja eredményről nem tud beszámolni, életjelnek az intézet elnökének nemzetközi szereplései tekinthetőek. Lásd: www. euskadi.eus/gobierno-vasco/-/asociacion/asociacion-international-institute-for-the-human-rightto-science-instituto-internacional-para-el-derecho-a-la-ciencia-zientziarako-giza-eskubidearen-aldeko-nazioarteko-institutoa/(2019.07.01.) 
tudományos munkájuk közvetve az okozója annak, hogy az őket „eltartó” közösségek is alacsonyabb szinten tudnak csak részesülni a tudomány eredményeiből. ${ }^{19}$ )

Csakhogy van egy ezzel ellentétes irány is, ahol a tudományos kutatás szabadsága ütközik az információs önrendelkezéssel (privacy). A tudományos kutatások bizonyos irányai - köztük elsősorban az úgynevezett „omikák”, amelyek az orvosbiológiai nagy személyes adatigényủ területeivel (genomika, proteomika, metabolomika) foglalkoznak - egyre inkább rászorulnak ugyanis arra, hogy vizsgálódásaikhoz tömegesen és megfelelő beleegyezések birtokában használhassák fel egyének mobil és viselhető eszközeinek érzékeny és bizalmas adatait. ${ }^{20}$

Mindkét esetben azt látjuk, hogy valójában a „tudományos üzemek” (scientific enterprises), és a velük összefonódott profittermelő mechanizmusok érdekei artikulálódnak jogként, és egyik színtéren sem a tudományhoz való jog aktualizálódik. S ugyanez igaz a látszatra nagyon is idesorolható követelésre, hogy a tudományos szakmákra is alkalmazzuk a nemi és faji kiegyensúlyozatlanság (gender and racial disparities) enyhítésének követelményét. A nők és a különböző bőrszínűek foglalkoztatásában elvárt arányosítás sem más, mint egy átfogóbb jog alkalmazása egy szükebb területre: az elvárt változásoknak ugyanúgy csak a népesség 1\%o-ét kitevő szakmai közösségen belül kellene érvényesülnie.

Jómagam azt is meglepőnek találom, hogy azok, akik követelményként megfogalmazzák, hogy a hozzáférés és a tudományoktatás révén a tudományos tudás és a módszer hasznából egyenlő módon részesüljön mindenki, mire hivatkozva teszik ezt. Milyen cél teljesüléséhez látják nélkülözhetetlennek? Erősen paternalista szemléletet tükröz, hogy a célfüggvény a tudással felvértezett (empowered) állampolgárok teremtése - egy még átfogóbb cél érdekében, hogy tudniillik ne egyszerúen tájékozottabbak lehessenek, hanem felelősségteljesebben tudjanak részt venni a szabad, tisztességes és demokratikus társadalmak építésében ${ }^{21}$ a bizonyítékalapú politikacsiná-

19 A hozzáférés legnagyobb gátjának tehát értelemszerűen a vagyoni-jövedelmi különbségek tűnnek. A gazdag és szegény országok között ugyanúgy, ahogy egy adott társadalom vagyoni, képzettségi, műveltségi rétegződései mentén. Mindez, lényegét tekintve, a tudománytermelésbe való becsatlakozásra feljogosító képességek alacsonyabb szintjére vezethető vissza. Ám az egyenlőtlenség-struktúrák mögött álló súlyos gazdasági, történeti és politikai szakadék megszüntetése és enyhítése a legmagasabb rendszerszinten fejeződik elsősorban ki: az, amit ebből a tudományokkal kapcsolatos, alapvetően következmény, kisebb részben az egyenlőtlenségek újratermelődésének egyik összetevője. Másképp: az egyenlőtlenség alapalgoritmusán nem a tudományhoz való jognak a hozzáférésen keresztül történő magasabb szintű érvényesítése változtathat. Egy itt elért elörelépés csak támogathat jóval komplexebb folyamatokat. Ez természetesen nem ok arra, hogy ne fürkésszük a hozzáférés kiterjeszthetőségének útjait, sokkal inkább azt a felismerést erősíti meg, hogy mégoly hangsúlyos jelenléte ellenére a hozzáférés kérdése sem a tudományhoz való jog fö terrénuma.

20 ManN 2018, 10822. Az ide tartozó projektek (lásd például www.personalgenomes.org és www. openhumans.org) esetében az is fontos szempont, hogy az adatközlők maguk is személyesen profitálhassanak a részvételből: a társadalmi hasznokon kívül az eredmények hajtsanak hasznot az egyéneknek is.

21 A 2. lábjegyzetben bemutatott felhívás (Appeal) félreérthetetlenül fogalmaz: „[S]cience education is an important element in creating more responsible citizens able to participate in the construction of free, fair, open democratic societies". 
lásban, ${ }^{22}$ és a civilizációs kihívások megoldását célzó tényalapú együttműködésekben (ahogy a második lábjegyzetben tárgyalt „Appeal” szerzői teszik).

Ezek a megközelítések tehát egy össztársadalmi szintre értelmezhető norma érvényesülését támogató csatornaként és erőforrásként tekintenek az állampolgárok fejében a tudomány révén felhalmozott tudásvagyonra. Ide nemcsak a „mit tudni” (ismeretelem), hanem a „hogyan tudni” (módszer), és a „kritikai apparátust mozgósítani tudni" (metamódszer) is beleértendő. Amit pedig mindezzel körülírnak, azt újabban tudományos müveltségnek (scientific literacy) nevezik egyre több szakmai diskurzusban. ${ }^{23}$ És ha a tudomány helyére a tudományos műveltséget állítjuk, mint egy specifikus emberi jog érvényesülésének tárgyát, egy csapásra megszűnik a korábbi dilemmák nagy része. Egyértelmű alakot ölt az, hogy „mi is az az entitás”, amelyhez fúződő jogot definiálunk, s rögvest nyilvánvaló válik az is, hogy itt már nem a sokaság 0,1\%-áról, hanem valóban a teljességéről van szó.

\section{A tudományos múveltség dimenziói}

Érdekes felismerni, miként fordult visszájára a közoktatási rendszer egyik régóta létező missziója, a tudományos utánpótlás-nevelés azzal, hogy a tudományok egy hányadának tantárgyként reprezentált közvetítése mellett a szakkörök és a tanulmányi versenyek révén elsősorban a „legtehetségesebbek”, a „legalkalmasabbak” számára nyitott ösvényt a 0,1\%-ba való kerüléshez. Ezzel de facto egyszerre ismerte el, hogy a tudományt magas rendű szellemi tevékenységnek tekinti, de erre csak kiváltságos keveseket tart alkalmasnak. Mindenki másnak meg kell elégednie azzal, hogy tudománytörténeti ismeretekhez jut (betekintést kap neves kutatók életébe, és tudományos eredményekhez tudja párosítani őket), módjában áll alacsony szintü tudományrendszertani mintázatokat felismerni, valamint elsajátíthatja néhány bázistudomány terminológiáját és alapismereteit. Ám mindez nem elég, jellemzően az is szükséges, hogy jól vagy részben jól informált felnőtt legyen a tudományos müveltség hordozója. ${ }^{24}$ Hiszen csak egy felnőtt képes olyan fundamentális műveltségre szert tenni, amelyre ráépülhet a (származtatott) tudományos írástudás. ${ }^{25}$ És amiként az írni tudás (literacy) még nem jelenti, hogy valaki magas szintű irodalmi szöveget tud létrehozni, valahogy ugyanígy tart maga között szakadékot a tudományosan müvelt (science

22 Wyndham-Vitullo 2018.

23 A tudományos írástudás fogalma 1958-ban született meg, de az előzményeket a 19. század végéig vezetik vissza. Rendszerező áttekintését lásd Jon Miller remek tanulmányában. MiLLER 1983.

A Daedalus c. folyóirat, amelyben a szöveg megjelent, egy egész tematikus számot (1983/2) szentelt ennek a kérdéskörnek.

24 Miller 1998.

25 Norris-Phillips 2003. 
literate) és a tudománymüvelésre képes (science-able) személy fogalma. ${ }^{26}$ És mindez már akkor így volt, amikor a tudományos műveltség helyett még a tudományos attitüd kifejezést használták. ${ }^{27}$ Valamennyi attribútumalapú meghatározás (milyen képességek, tudások, ismeretek és érzékenységek teszik ki a tudományos írástudást) a használat, alkalmazás és az ismerethez való viszony szempontjaira érzékeny. ${ }^{28} \mathrm{Az}$,ismerni/érteni” és a „használni” követelménye része a meghatározásoknak, a „művelni” (doing) nem. ${ }^{29}$

Még amikor már (végre) azt a kérdést teszik fel a kutatók, hogy mit is jelent „csinálni" a tudományt, ${ }^{30}$ akkor is inkább a kísérletező diák képe rémlik fel, aki

- tapasztalati bizonyítékok alapján képessé válik fizikai, fogalmi vagy matematikai modelleket építeni;

- ért és használ már létező modelleket;

- felfogja és érti a tudomány(osság) határait;

- képes kísérleteket tervezni, hogy tesztelje a modelljét.

Ezzel azonban még mindig nem lesz más a tudományképes felnőtt vagy diák, mint kompetens kívülálló (competent outsider). Ez kétségkívül jobb ugyan, mint a marginális bennfentes pozíciója, amit a hagyományos (tudomány)oktatásnak köszönhettünk, ${ }^{31}$ ahol a tudomány mechanizmusaival kapcsolatos megértés kezdetleges szintje ahhoz elég csak, hogy lelohassza az érdeklődést, és a tudományos életben való részvételre való alkalmatlanság érzését sulykolja. Azzal, hogy az oktatás immár arra is alkalmassá kívánja tenni a diákokat, hogy tudományos ismereteket mint erőforrást szólítsanak magukhoz, kombinálják azt saját tapasztalataikkal, és véleményüket vagy döntésüket ennek alapján alakítsák, illetve hozzák meg, azzal a tudomány hasznosságának téziséhez térnek csupán vissza. Ha valaki képes a hétköznapi életben kutatási eredmények használatára, esetleg saját „kutatás” lefuttatására, azzal kutatásképessé (research literate) válik, rendelkezik majd kutatásműveltséggel (research literacy) - de szerepe továbbra sem lesz más, mint a kritikai jártassággal felvértezett, tájékozott fogyasztóé. ${ }^{32}$

Amikor bevezették az akadémiai müveltség/írástudás (academic literacy) fogalmát, akkor voltaképp ugyanezt a képességegyüttest emelték „feljebb”, jellemzően a felsőoktatás diákjainak a világába, a magas szintű szöveges produkcióik elóállításához szükséges speciális ismereteket kifejező kategóriaként. S mivel gyakorta az idegennyelvtudás szintjével (proficiency) együtt tárgyalják, ${ }^{33}$ megfelelő hasonlatnak kí-

26 Ezt a kettősséget megzavarni látszik, hogy a „science-able student” szerkezettel a pedagógiai irodalom azokat a diákokat illeti, akik jobb eredményekkel rendelkeznek a tudomány-tantárgyakban, ami mögött nagyobb affinitásuk és érdeklődésük áll. BOEVE-DE PAUw 2011, 59-66. A tudományképesség értelmezésünkben tudományos tevékenység folytatására való alkalmasságot jelent, és nem eredményesebb mivoltot a tudományokkal kapcsolatos tudásokról való számadáskor.

28 LAUGKSCH 2000.

29 HAZEN-TrefiL 1991.

30 Allain 2015.

31 FEINSTEIN 2011.

32 BeAudry-Miller 2016.

33 READ 2015. 
nálkozik a tudományt is úgy megközelíteni, mint egy „nyelvet”: aki elsajátítja, az képes kommunikálni és jelentéseket cserélni (adni és kapni), ám ettől még nem válik a tudomány képviselőjévé. Továbbra is nagyon kompetens kívülálló marad - amivel rendelkezik, az az állampolgári tudományműveltség (civic science literacy), amihez elsősorban a felsőfokú tanulmányai segítik. ${ }^{34}$ Hogy aztán ezt alkalmazni tudja a szakmai vagy lakóközösségén belül, hogy felvértezi magát kritikai müveltséggel, hogy tud és mer kérdezni és visszakérdezni, jelenséget leírni vagy előre jelezni, tudományos vagy sajtóhírek állításaihoz viszonyt kialakítani, bizonyítékalapú információkat argumentációba építeni - bármire is képes lesz ezáltal, ${ }^{35}$ egyetlen egy dologra nem: hogy ő maga hozzon létre tudományos eredményt, illetve részese legyen olyan alkotóközösségnek, amely tudományos értéket termel.

\section{Az utolsó lépés előre: a tudománymüvelésre való képességhez füződő jog értelme és esélyei}

Az ENSZ közgyülése számára 2012-ben átfogó jelentés készült, ${ }^{36}$ amely 24 normatív pontban foglalta össze a tudományhoz való jog mibenlétét. Ezek a pontok négy alapvető jogosztályba rendeződnek, és ezekből hármat már jól ismerünk korábbról: 1. mindenki diszkriminációmentes hozzáférése a tudomány eredményeihez, 2. egyének és közösségek részvétele a tudománnyal kapcsolatos döntéshozatali folyamatban, és 3. a tudomány és a technológia eredményeinek fejlesztése, szétterítése és megőrzését szolgáló környezetek erősítése.

A negyedik elem azonban vadonatúj és a jogi kontextusban előzmény nélküli: 4. „mindenkinek lehetöséget kell biztositani arra, hogy hozzájárulhasson a tudományüzem termeléséhez: ehhez elengedhetetlen a tudományos kutatásba való bekapcsolódás szabadsága”. ${ }^{37}$

A szöveg megszületésének évszámára, 2012-re pillantva meglepő, hogy csak most öltött testet ebben a formában ez a jogként definiált igény. A valóságban ugyanis már régóta nyer egyre nagyobb teret a tudományos hivatásrenden kívüli szereplők bevonása a tudományos kutatásokba.

Az egyesek bekapcsolódása nagyjából kétszáz éve a semlegesebb amatőr tudós szerepen keresztül ment végbe. Ha az individuális tudástermelés eredménye elfogadható és minőségbiztosítható volt a tudományos közösség számára, akkor az autodidaktákat

34 Miller 1998.

35 A legtartalmasabb képesség-felsorolást lásd: RoBERTs 2007; A legszélesebb értelemben vett tudományos műveltség legszenvedélyesebb népszerüsítésére lásd Andrew Zwicker nagy látogatottságú TED-előadását. Lásd: www.youtube.com/watch?v=b-EsmVbIjLU (2019. 07. 01.)

36 A szöveget a Farida Shaheed-vezette bizottság széleskörű konzultációs és vitafolyamat után véglegesítette, amelyben nemcsak a tagállamok, hanem a tudomány képviselői és számos civil szervezet is részt vett. A jelentés teljes szövege hozzáférhető itt: www.ohchr.org/Documents/HRBodies/ HRCouncil/RegularSession/Session20/A-HRC-20-26_en.pdf (2019. 07. 01.)

37 „OO]pportunities for all to contribute to the scientific enterprise and freedom indispensable for scientific research." A 24 pontot részletesen bemutatja: MANCISIDOR 2017, 211-221. 
mint (szuper)kompetens kívülállókat akár intézményesen is integrálták, részlegesen felhatalmazott bennfentessé téve őket. ${ }^{38}$ (Gondoljunk csak a tudománytörténet széles körben ismertté vált amatőr régészeire és csillagászaira, tengerbiológusaira, botanikusaira, vagy azokra a tanárokra és papokra, akik neves helytörténetíróvá váltak.) Ha kánonon és minőségen kívülinek bizonyultak az amatőrök szellemi termékei, akkor a lenéző hobbitudós címkét kapták meg, ha veszélyesnek és kútmérgezőnek is tartották az eredményt, akkor a tudomány képviselői azt az áltudomány (parascience, pseudo-science) minősítéssel igyekeztek dehonesztálni. (Csak összezavarva a jóval teljesebb színképet azzal, hogy áltudományt és csalást a hivatalos tudományművelők is gyakran követnek el, és a tudományos tévedések tudományon kívüli kiigazítóival szemben is gyakorta automatikus reflex a „ledilettánsozás”)

Ám az igazi újdonság a közösségi részvétel, a közösségi bekapcsolódás a tudástermelő folyamatokba, amelyet az állampolgári tudomány (citizen science) paradigmája foglal össze. Ez is már több mint százéves, hiszen a megfigyelésigényes ornitológiában a 20. század legelején intézményesedett a hivatásrend és az érdeklődő, felkészült állampolgárok szövetsége (a National Audubon Society azóta is zajló karácsonyi madárszámlálásával). ${ }^{39}$ Egy olyan közösség megteremtésével, ahol a jól minőségbiztosítható és szétosztható aprócska részfeladatok (microtasks) végzésébe bekapcsolódó sokak és a magasrendű tudásműveletekkel a felhalmozott szórványadatokat szintetizáló kevesek teljesértékủ együttmüködésével születnek az új tudományos eredmények.

E mögé a „szövetségtípus” mögé „gyújtott” új rakétákat a digitális és hálózati forradalom. Először még csak processzoraik kihasználatlan gépidejét ajánlhatták fel önkéntes tudományos projektek számításteljesítményének növelésére a felhasználók, hogy hamarosan „humán processzorként” kövesse mindezt szemükkel összekapcsolt agyuk, játékos kedvük és életidejük, tudományos kutatások céljaira. A „crowdsource", az önkéntes erőforrásszerzés világán belül rövid idő alatt a tudományos programokhoz való csatlakozás lett a legnépszerủbb, tízmilliókat megmozgató tevékenység, és mostanáig több száz, sikeres, nagy és kisebb volumenű program futott le a weben,

38 Más szakmavilágokban, a művészeti életben vagy a hivatásos sportolók világában is ugyanez a folyamat ment végbe: amikor az amatőr teljesítménye összevethető a hivatásrend kiképzett tagjaiéval, akkor a professzionális amatőrök (ProAms), félprofesszionálisak (SemiPro's) számára megnyílnak az utak az adott közösségek elfogadott tagjává váláshoz. A diskurzust a Demos kutatóinak, Charles Leadbeaternek és Paul Millernek a ProAm-forradalomról írt 2004-es jelentése indította el (LEADBEATER-MilLER 2004), nem meglepő módon a fő sodor azonban azóta a hagyományos hivatásrendek szertartásosan definiálási igyekezete, hogy az integrációs nyomás ellenére milyen különbségek maradnak a professzionálisak és az amatőrök között. Néhány jellemző érv és megközelítés: (a szoftverfejlesztésben) www.mountaingoatsoftware.com/blog/the-difference-between-a-professional-and-an-amateur; (az előadóművészetben) https://spotlitesblog.wordpress.com/2013/10/01/ professional-versus-amateur-in-performance/; (a videoalkotások létrehozásában) www.business2community.com/video-marketing/amateur-vs-professional-video-production-5-ways-tell-difference-01899024. A különbségek természetesen léteznek: remek összefoglalójukat lásd: https://medium.com/@jeffgoins/the-7-differences-between-professional-and-amateurs-ab6850c25c61 még részletesebben: https://fs.blog/2017/08/amateurs-professionals/ (2019. 07. 01.) www.audubon.org/conservation/science (2019. 07. 01.) 
sokszor milliós (!) tudományos segédhadseregekkel. ${ }^{40}$ Új lendületet adott a lehetőségek kiterjesztésének az okostelefonok tömegessé válása, amivel minden önkéntes a korábbiakon felül egy „mozgó laboratórium” teljesítményét is a közös célok érdekébe tudja állítani. S ahol a „dolgok internetjének” távcsövei, mikroszkópjai, szenzorai és webkamerái termelik zettabyte-számra az adatokat, ott is egyre nagyobb az igény az evolúció által képfelismerésre, mintázatfelismerésre és értelmezésre „fejlesztett” agyak tömeges bevonására. Az állampolgári tudomány iránti egyre nagyobb igényt és az ezen alapuló projektek hatékonyságát felismerve az Egyesült Államok 2017. január 6-án léptetett hatályba egy új törvényt. A Crowdsourcing and Citizen Science Act nemcsak népszerüsíti a tudományos tudás termelésének ezt a formáját, hanem egyenesen előírja a közszférának ott, ahol ezzel kiváltható forrás. ${ }^{41}$

Annak hangsúlyozásával, hogy a microtaskalapú feladatmegosztás csak a tudományos kutatások jól körülhatárolható, kisebb részénél valósítható meg, és hogy az előképzettség nélküli önkéntesek részvételével szemben nem jelent meg érdemleges ellenállás, az emberi jogi dimenziót sem a hagyományos szabadságjogok környékén kell keresnünk. Sőt, arra a kérdésre is választ kell kapnunk, hogy mi az oka annak, hogy egyáltalán ,jogként” vetődjön fel a tudományművelésben való aktív részvétel.

Véleményem szerint tudomány és ember megváltozó viszonyának az alapvető okát a társadalmi makroevolúció aktuális állapotában találjuk meg.

Makroszinten abban, hogy a társas lét korábbi, szabályozást és reflexiót igénylő rétegei fölé fokozatosan egy újabb, minden korábbinál nagyobb, és nagyobb komplexitású rendszer épül. A planetáris cselekvőközösségként felfogott emberiség képe nem leváltja a korábbi képzeteket, hanem azok mellé sorakozik fel, mint egy új „földtani réteg”. Az arányokat változtatja meg, azzal összefüggésben, ahogy a legátfogóbb rendszerszinten jelentkező civilizációs kihívások a legátfogóbb rendszerszinten érvényesülő koordinációs, érdekegyeztetési, kommunikációs és döntési teret és kényszert teremtenek, és ezeknek egyre inkább meghatározóvá kell válniuk a többivel szemben. A megfelelő cselekvésekhez vezető ismereteket megtermelő tudományos megismerés is egyre nagyobb összefogást és egyre több erőforrást igényel. A legfőbb kérdés tehát az, hogyan legyünk bolygónk jobb gondnokai. ${ }^{42}$ A jogok valamiféle egyetemlegessége mögött a felelősség és a lehetőség ezen új dimenziói húzódnak meg.

Mikroszinten a jóléti társadalmaknak köszönhetően megváltozó emberkép felől kell elindulnunk. A társadalomtörténet modernitás előtti szakaszai a túlélésparan-

40 A legismertebb ilyen tudományos vállalkozás mai napig az újonnan felfedezett csillagászati objektumokat osztályozó Galaxy Zoo-projekt volt (http://zoo1.galaxyzoo.org/). A 2000-ben indult, a közösségi médiát remekül használó Folding@Home https://foldingathome.org/ és a 2008-ban indult FoldIt-projekt (https://fold.it/portal/) fehérjeszerkezetek „csomagolásával” való kísérletezésre bírja rá a játékos kedvű önkénteseket, mai napig fut, és termeli az új felfedezéseket, kihasználva az emberi elme nagyobb kreativitását a gépi algoritmusokkal szemben. Az állampolgári tudományra építő legtöbb projekt környezeti és ökológiai kérdésekkel foglalkozik.

41 Z. Karvalics 2019.

42 „Better stewardship of the planet”. Anelli szavait idéztük, aki a tudományos műveltségben látja a garanciáját a felelősebb bolygókormányzásnak. Lásd: ANELLi 2011. 
csok nyomása alatt kényszerủen az emberi lét partikuláris mozzanataira építhettek - elsősorban a munkavégzési képességre. Amikor a munkamegosztás fejlettsége és az értéktöbblet-termelés volumene lehetővé tette, hogy a termelésből (sok más információ- és tudásmunkás mellett) először csak néhányan, a 18. századtól már valamivel többen, a 19. század utolsó harmadától pedig már tömegesen legyenek kiemelhetők azok, akik a tudomány alrendszerét müködtetik, ezzel párhuzamosan a tudományművelésnek egy elitista szemlélete uralta el a közbeszédet. Pedig a tudomány - mondja Orzel - „nem valami idegen, kifürkészhetetlen világ” az átlagember számára. ${ }^{43}$ Egyenesen az emberi lét és emberi tapasztalat szükségszerủ velejárója, hiszen számtalan helyzetben úgy „viselkedünk” mintha a tudományos módszer vezetné a tetteinket. A tudomány ilyen értelemben folyamat, amelynek révén megismerő erőnk fokozása cselekvési hatékonyságunk növelését eredményezi. Ebben az értelemben azok is élnek a tudománnyal, akik azt gondolják, hogy gyülölik vagy soha nem érthetik azt meg. Pedig magát a tudományt és a tudományos módszert sem tudósok teremtették, hanem „közemberek”: Liebenberg azt bizonyítja be, hogy a tudomány ősi forrása a vadászó és környezetével harmóniában élő ökotudatos homo sapiens - már a neolitikumban. ${ }^{44}$ Conner a bányászok, bábák, kézművesek és agrártermelők ókori és koraújkori világaiba kalauzol, ${ }^{45}$ akiknek az apró és szakadatlan innovációiból, a természet, az élő anyag és az emberi test megismerésében elért praktikus eredményeiből nőtt ki mindaz, ami aztán a megismerést és a technológiát iparosította. A modern tudomány szülője a „közemberek tudománya” (people’s science). Ilyen értelemben paradox módon a modern tudomány mint hivatásrend létrejötte pillanatában „kiemelte magát” szülőrendszeréből, és önmagát annak fölébe helyezte. Amikor „mindenki tudományhoz való jogáról” beszélünk, ennek ebben az értelemben van emancipációs üzenete. Ha „a tudomány az, ami emberré tesz minket” („science is what makes us human"), ${ }^{46}$ nem törődhetünk bele, hogy az emberiség elsöprő többsége kívül reked az intézményes sáncokon, és az egész oktatási rendszer sem más, mint ennek a programozott eltávolításnak a médiuma. Különös tekintettel arra, hogy a pedagógiai irodalomban ma már közhely, hogy a világot felfedező gyermeki elme a fogalomalkotás, kategória- és mintázatképzés műveleteivel, a (rá)kérdezés aktusával szintén arra a rugóra jár, mint maga a tudomány, hogy a gondolkodni tudást kiszorítsa a munkaerőpiaci igényeket kiszolgáló ismeretcsomagok birtoklásának képessége.

A fordulatnak tehát az iskolában kell kezdődnie. A tantárgyként, mégoly érdekesen prezentált tudományos alapismeretek mellett az idő egy részét mind kiérleltebb didaktikai háttérrel a civilizációs és helyi, társadalmi és ökológiai problémák azonosítását követően a megoldásban való aktív részvétel pályáinak a keresésével töltve, bekapcsolódva az ilyen irányba mutató tudományos programokba (tanárnak és diáknak egyaránt). Természetesen mindazok kivételével, akik életpályaként választják a tudós-

43 Orzel 2014.

44 Liebenberg 1990.

45 CONNER 2005.

46 Orzel 2014. 
létet, mindenki más is továbbra is része maradhat az ilyen értelemben új generációsnak tekinthető állampolgári tudománynak, saját érdeklődése, kedve, ideje, felelősségés szolidaritásfelfogása okán. Az élethosszig tartó tanulás (lifelong learning) mellé így zárkózik fel a lifelong research, az élethosszig tartó kutatás. ${ }^{47}$ A közösségbe belépő új generációk a megfelelően támogatott és fejlesztett tudományos műveltségük révén már egészen fiatal korban is alkalmassá válnak arra, hogy aktív résztvevői legyenek a civilizációs kihívásokkal való megküzdésnek. Jog, felelősség és lehetőség háromszögének a törzsi beavatási szertartásokra emlékeztető világa így éledhet újra az információs korszak társadalmában. A tudományművelést diákként megkezdő polgárokat ezért neveztem korábban digitális beavatottaknak. ${ }^{48}$

A tudományműveléshez való jog, és ennek alépítménye, a tudományos műveltség, és kerete, az állampolgári tudomány így nyer új értelmet a civilizációs változás kontextusában. ${ }^{49} \mathrm{Az}$ ekképpen felfogott tudományhoz való jog immár része a jogok egy újonnan felépülő családjának, amely egyelőre még az új műveltségformák felől cserkészhető be leginkább érzékelhető módon. Capra ${ }^{50}$ a rendszerproblémák összekapcsolt természetéből kiindulva az ökológiai müveltség (ecological literacy), az UNESCO pedig a jövőmüveltség (futures literacy) fontosságát hangsúlyozza. Egy másik irányból az írástudásként felfogott részvételiség (participative literacy), és a korábban megfogalmazott kritikai műveltségtípusokon túllépő radikális információs müveltség (radical information literacy) ${ }^{51}$ körvonalazza a lassú közeledést a civilizációs jogok (civilization rights $)^{52}$ vagy a negyedik generációs emberi jogok világához.

Soh és társai ${ }^{53}$ a "negyedik ipari forradalom" kontextusában vélik úgy, hogy az anyagi, biológiai és digitális technológiák összefonódása és az emberiség kölcsönös összekapcsoltságának új minősége által felvetett alapvető egzisztenciális kérdések és veszélyek teszik szükségessé a „negyedik generációs emberi jogokról” szóló párbeszéd megindulását. Mások szerint ezek csak az emberi jogok generációinak 1979-es első

47 Z. Karvalics 2013a.

48 Z. Karvalics 2013b.

49 Z. Karvalics 2013c.

50 CAPra-Luisi 2014.

51 WhitworTh 2015.

52 A „civilizációs jogok” fogalma még kiforratlan és ellentmondásos. Elsősorban azért, mert használóinak egy része nem rendszertudományi, hanem kultúraelméleti értelemben használja. Náluk a nemzetállami szint felett ugyan („keresztény civilizáció”), de a planetáris szint alatt helyezkedik el, és a kihívás a nemzetközi jog civilizációköziségének fürkészése. Gozzi 2019. Newt Gingrich szótárában (a 2015. január 24-i, az Iowa Freedom Summiton tartott beszéde szerint) „a civilizációs jogok felülírják a polgárjogokat” (és ezzel azt fejezi ki, hogy a nemzet védelme érdekében a polgárjogok nem mindenkire érvényesek, aki másik civilizációt képvisel). Lásd: www.youtube.com/ watch?v=cFVvYsAB1xw (2019. 07. 01.). Meglepő módon egy szubkulturális mű, a Biblia stílusában íródott „A Hip-hop evangéliumának” megközelítése áll a legközelebb ahhoz az értelmezéshez, amelyet képviselek: „Tegnap még polgárjogokat igényeltünk, ma már civilizációs jogokat: hogy megteremthessük, meghatározhassuk és kormányozhassuk magunkat.” 125. zsoltár. KRS-ONE 2009. Soh-Connolly-Nam 2018. 
megfogalmazásakor ${ }^{54}$ már viszonylag jól körülírt (és a zöld színnel jellemzett) harmadik generációs emberi jogokhoz sorolt területek új hajtásai, variációi. Hiszen a biológiai sokszínűséget, a genetikai módosítások/klóntechnika által felidézett veszélyekkel szembeni tudatosságot, a fenntarthatóság, a jövő nemzedékek szempontjainak figyelembevételét, a kulturális örökség „átmentésének” fontosságát és a megváltozó léptékủ információs és kommunikációs környezethez való alkalmazkodást kivétel nélkül beleérthetjük a "globális jogok" és a csoportjogok közé (ahol a csoport maga az emberiség). ${ }^{55} \mathrm{Ha}$ innen közeledünk, mindenki mély és személyes érintettsége az, ami a műveltség és a részvételiség igényét kiterjeszti a tudományművelésre is, amely épp a fenti kérdésekkel tusakodik.

Érdekes mindezt azzal szembesíteni, hogy - mint azt a tanulmány elején láttuk - a tudománnyal kapcsolatos emberi jogok egyes vonatkozásai a (piros színnel jellemzett) második generációs emberi jogok kapcsán merültek fel, a társadalmi és kulturális egyenlőség kontextusában. Nem kétséges azonban, hogy tekinthetünk akár úgy is rá, mint az alapvető állampolgári és politikai jogok első („kék”) generációjára nézve is részben érvényes kérdésre. Hiszen a kiterjesztett egyenlőség-eszmény és az emberi méltóság is sérül, ha a szocializáció alaprendszerei úgy épülnek fel, hogy indirekt módon elfogadják, sőt erősítik és termelik a sajátos „kognitív diszkriminációt” a tudománymüvelésre való alkalmasság kapcsán. ${ }^{56}$

Bárhogy is alakul a „besorolás”, a tudománymüveléshez való jog része annak a folyamatnak, ahogyan a 18. század végétől az emberi jogok tartalma együtt bővül a jogalanyok körével, és a mindebben földrajzilag érintett területekkel. ${ }^{57}$ Szemléletileg minden kész ahhoz, hogy az emberiséggel és a globális minőséggel elért, már nem meghaladható határokon belül a tudományművelés kiterjesztésének és társadalmasí-

54 A felosztást az emberi jogok három generációjáról Karel Vasak cseh jogász 1979-ben javasolta Strasbourgban (International Institute of Human Rights), és felvetése a szakirodalomba és a jogalkotásba is utat talált.

55 Érdekes, hogy ugyanezeknek a területeknek a nagy részéről Áder János köztársasági elnök is olyan „negyedik generációs alapjogokként” beszélt az ENSZ Közgyủlése 67. ülésszakának általános vitájában 2012. szeptember 25-én, amelyekre a 2011-es magyar alkotmány már reflektál is. www.keh.hu/ v9-Ader_Janos_beszede_az_ENSZ_kozgyulesen\&pnr=1 (2019.07.01.)

56 Ki kell rá röviden térni, hogy valóban kialakul egy „kognitív szakadék”, viszonylag gyorsan, ami miatt embertársaink egy részére látszólag igaz lesz a „tudományképtelenség” tézise. Közismert ugyanakkor, hogy nincs „eleve alkalmatlan” mivolt, de mindenki alkalmatlanná tehető - például azzal, hogy deprivált környezete, írástudatlansága vagy oktatási szegregáltsága a nyelvi-kommunikációs és gondolkodási képességeit nem, vagy sokkal lassabban fejleszti. (Az éhezés például nemcsak az egészségre és az életesélyekre, hanem - mérhető módon - a szellemi képességek kibontakozására is negatív hatással van). Ahogy Kondorosi helyesen mutat rá, hogy már az emberi jogi párbeszédbe sem lehet becsatlakozni bizonyos alapjogok biztosításának hiányában, ugyanúgy igaz, hogy nincs tudományműveléshez való egyetemes emberi jog a Mészáros István által normaként megjelenített lényegi egyenlőség (substantive equality) nélkül. Lásd: KONDOROsi 2016; MÉszÁros 2016. A remélt átmenet időszakában mindez a „szerzett és társadalmilag újratermelt kognitív hátrányok minőségi és valódi korrekciójához való jog" formájában ölthetne testet.

KÖRNYEI 2011, 5. 
tásának programja ne csak szigetszerű gyakorlattá, hanem egyre mélyebben és gazdagabban megélt közösségi és intézményi normává váljon.

\section{Felhasznált irodalom}

Allain, Rhett (2015): What does scientific literacy really mean? Wired, Aug, 28. Elérhető: www.wired.com/2015/08/scientific-literacy-really-mean/ (2019. 07. 01.) DOI: https://doi.org/10.1093/ ae/57.4.235

Anelli, Carol (2011): Scientific Literacy: What Is It, Are We Teaching It, and Does It Matter? American Entomologist, Vol. 57, No. 4. 235-244. DOI: https://doi.org/10.1093/ae/57.4.235

Beaudry, Jeffrey S. - Miller, Lynne (2016): Research Literacy. A Primer for Understanding and Using Research. Guilford Press.

Boeve-De Pauw, Jelle (2011): Valuing the invaluable. Effects of individual, school and cultural factors of environmental values of children. Antwerpen/Apeldoorn, Garant.

Bowers, Sarion (2018): Science as a human right. Wellcome Sanger Institute Blog, Nov.19. Elérhető: https://sangerinstitute.blog/2018/11/09/science-as-a-human-right/ (2019.07. 01.)

CAPra, Fritjof - Luisi, Pier Luigi (2014): The systems view of life: a unifying vision. Cambridge, Cambridge University Press. DOI: https://doi.org/10.1017/CBO9780511895555

Chapman, Audrey - Wyndham, Jessica (2013): A Human Right to Science. Science, Vol. 340, No. 6136. DOI: https://doi.org/10.1126/science.1233319

Conner, Clifford D. (2005): A People's History of Science. New York, Nation Books.

DAvis, Ira C. (1935): The measurement of scientific attitudes. Science Education, Vol. 19, No. 3. 117-122. DOI: https://doi.org/10.1002/sce.3730190307

Donders, Yvonne (2009): The Right to Enjoy the Benefits of Scientific Progress and its Applications. Report of the Experts' Meeting, Venice, 16-17 2009. UNESCO.

Feinstein, Noah (2011): Salvaging science literacy. Science Education, Vol. 95, No. 1. 168-185. DOI: https://doi.org/10.1002/sce.20414

Gozzi, Gustavo (2019): Rights and Civilizations: A History and Philosophy of International Law. Cambridge, Cambridge University Press. DOI: https://doi.org/10.1017/9781108565035

Hazen, Robert M. - Trefil, James (1991): Science matters. Achieving scientific literacy. New York, Anchor Books Doubleday. DOI: https://doi.org/10.1119/1.17073

LaugKsCH, Rüdiger C. (2000): Scientific Literacy: A Conceptual Overview. Science Education, Vol. 84, No. 1. 71-94. DOI: https://doi.org/10.1002/(SICI)1098-237X(200001)84:1<71::AIDSCE6 $>3.0 . C O ; 2-\mathrm{C}$

KONDOROSI Ferenc (2016): Emberi jogok és kultúrák. Eszmélet, 28. évf. 109. sz. 26-40.

KÖRNYEI Ágnes (2011): Emberi jogok a nemzetközi kapcsolatokban. Piliscsaba, PPKE BTK.

KRS-ONE (2009): The Gospel of Hip Hop: First Instrument. powerHouse Books.

Leadbeater, Charles - Miller, Paul (2004): The Pro-Am Revolution: How Enthusiasts Are Changing Our Society and Economy. London, Demos.

Liebenberg, Louis (1990): The Art of Tracking. The Origin of Science. David Philip.

Mancisidor, Mikel (2015): Is There Such a Thing as a Human Right to Science in International Law? ESIL Reflections, Vol. 4, No. 1.1-6.

Mancisidor, Mikel (2017): El derecho humano a la ciencia: Un viejo derecho con un gran futuro. Anuario de Derechos Humanos, Vol. 13. 211-221. DOI: https://doi.org/10.5354/07182279.2017.46887 
Mann, Porsdam S. - Donders, Y. - Mitchell, C. - Bradley, V. J. - Chou, M. F. - Mann, M. Church, G. - Porsdam, H. (2018): Advocating for science progress as a human right. PNAS, Vol. 115, No. 43. 10820-10823. DOI: https://doi.org/10.1073/pnas.1816320115

MÉszáros, István (2016): From Primitive to Substantive Equality - via Slavery. Monthly Review, Vol. 68, No. 4. 33-56. DOI: https://doi.org/10.14452/MR-068-04-2016-08_4

Miller, Jon D. (1983): Scientific Literacy: A Conceptual and Empirical Review. Daedalus, Vol. 112, No. 2. 29-48.

Miller, Jon D. (1998): The measurement of civic scientific literacy. Public Understanding of Science, Vol. 7, No. 3. 45-68. DOI: https://doi.org/10.1088/0963-6625/7/3/001

NAgy Lászlóné - NAgY Márió Tibor (2016): Kutatásalapú tanítás-tanulás a biológiaoktatásban és a biológiatanár-képzésben. Iskolakultúra, Vol. 26, No. 3. 57-69. DOI: https://doi. org/10.17543/ISKKULT.2016.3.57

Norris, Stephen P. - Phillips, Linda M. (2003) How literacy in its fundamental sense is central to scientific literacy. Science Education, Vol. 87, No. 2. 224-240. DOI: https://doi.org/10.1002/ sce.10066

Orzel, Chad (2014): Eureka: Discovering Your Inner Scientist. Basic Books.

READ, John (2015): Defining and Assessing Academic Literacy. In READ, John: Assessing English Proficiency for University Study. London, Palgrave Macmillan. 137-161. DOI: https://doi. org/10.1057/9781137315694_7

Roberts, Douglas A. (2007): Scientific Literacy/Science literacy In Abell, Sandra K. - Lederman, Norman G. eds.: Handbook of Research on Science Education Lawrence Erlbaum Associates. Routledge. 729-780.

SoH, Changrok - Connolly, Daniel - Nam, Seunghyun (2018): Time for a Fourth Generation of Human Rights? UNRISD Think Piece Series, March 1. Elérhető: www.unrisd.org/TechAndHumanRights-Soh-et-al (2019. 07. 01.)

Whit worth, Andrew (2015): Radical Information Literacy Chandos Publishing. DOI: https://doi. org/10.1016/C2013-0-16971-1

Wyndham, Jessica M. - Vitullo, Margaret Weigers (2018): Define the human right to science (Editorial). Science, Vol. 362, No. 6418. 975. DOI: https://doi.org/10.1126/science.aaw1467

Z. Karvalics, László (2013a): From Scientific Literacy to Lifelong Research: A Social Innovation Approach. In KurbanoĞlu, Serap - Grassian, Esther - Mizrachi, Diane - Catts, Ralph - ŠPIRANEC, Sonja eds.: Worldwide Commonalities and Challenges in Information Literacy Research and Practice European Conference on Information Literacy. ECIL Istanbul, Turkey, October 22-25, 2013 Revised Selected Papers Springer. 126-133. DOI: https://doi.org/10.1007/9783-319-03919-0_15

Z. KARVALICs László (2013b): „Digitális beavatottak” egy hiperkonnektív világban. In SzEKSzÁRDI Júlia szerk.: Digitális (de)generáció 2.0. Budapest, Underground Kiadó, 62-78.

Z. KARVALICs László (2013c): „Jelentés-teli világra nyíló szárnyas kapu”. Egy logokratikus médiapedagógia körvonalai. In PÁLFi Erika szerk.: Médiatudatosság az oktatásban. Konferenciakötet. Budapest, OFI. 53-59.

Z. KARVALICs László (2019): Állampolgári tudomány és önkéntes erőforrásszerzés mint paradigmatikus, szakpolitikai és menedzsment-kihívás. Új Magyar Közigazgatás, 12. évf. 1. sz. 44-53.

Zsolnai József (2005): A tudomány egésze. A magyar tudomány tudománypedagógiai szemléje. Budapest, Müszaki Kiadó. 


\section{Internetes források}

Áder János beszéde az ENSZ-közgyülésen (2012). Elérhető: www.keh.hu/v9-Ader_Janos_beszede_ az_ENSZ_kozgyulesen\&pnr $=1$ (2019.07.01.)

Andrew Zwicker TED-elöadása. Elérhető: www.youtube.com/watch?v=b-EsmVbIjLU (2019. 07. 01.)

Appeal For The Right To Science. Elérhető: www.freedomofresearch.org/appello/ (2019. 07. 01.)

Audubon Science. Elérhető: www.audubon.org/conservation/science (2019. 07. 01.)

Cohn, Mike (2018): The Difference Between a Professional and an Amateur. Elérhető: www.mountaingoatsoftware.com/blog/the-difference-between-a-professional-and-an-amateur (2019. 07. 01.)

Folding at Home. Elérhető: https://foldingathome.org/ (2019. 07. 01.)

Galaxy Zoo. Elérhető: http://zoo1.galaxyzoo.org/ (2019. 07. 01.)

Goins, Jeff (2016): The 7 Differences Between Professionals and Amateurs. Elérhető: https://medium.com/@jeffgoins/the-7-differences-between-professional-and-amateurs-ab6850c25c61 (2019. 07. 01.)

International Covenant on Economic, Social and Cultural Rights. United Nations Human Rights. Elérhető: www.ohchr.org/en/professionalinterest/pages/cescr.aspx (2019. 07. 01.)

International Institute for the Human Right to Science. Elérhető: www.euskadi.eus/gobierno-vas$\mathrm{co} /$-/asociacion/asociacion-international-institute-for-the-human-right-to-science-institutointernacional-para-el-derecho-a-la-ciencia-zientziarako-giza-eskubidearen-aldeko-nazioarteko-institutoa/ (2019. 07. 01.)

International Science Council. Elérhető: https://council.science/ (2019. 07. 01.)

Marsh, Steph (2017): Amateur vs. Professional Video Production: 5 Ways to Tell the Difference. Elérhető: www.business2community.com/video-marketing/amateur-vs-professional-video-production-5-ways-tell-difference-01899024 (2019. 07. 01.)

Newt Gingrich - Iowa Freedom Conference. Elérhető: www.youtube.com/watch?v=cFVvYsAB1xw (2019. 07. 01.)

Open Humans. Elérhető: www.openhumans.org (2019. 07. 01.)

Professional versus Amateur in performance (2013). Elérhető: https://spotlitesblog.wordpress. com/2013/10/01/professional-versus-amateur-in-performance/ (2019. 07. 01.)

Report of the Special Rapporteur in the field of cultural rights (2012). UN. Elérhetö: www.ohchr. org/Documents/HRBodies/HRCouncil/RegularSession/Session20/A-HRC-20-26_en.pdf (2019. 07. 01.)

Science as a human right: the need of a unified concept (2018). Elérhető: https://en.unesco.org/news/ science-human-right-need-unified-concept (2019. 07. 01.)

Solve Puzzles for Science. Elérhető: https://fold.it/portal/ (2019. 07. 01.)

The DifferenceBetween Amateurs and Professionals. Farnam Street. Elérhető: https://fs.blog/2017/08/ amateurs-professionals/ (2019. 07. 01.)

The Personal Genome Project. Elérhető: www.personalgenomes.org (2019. 07. 01.)

Universal Declaration of Human Rights. UN. Elérhető: www.un.org/en/universal-declaration-human-rights/ (2019. 07. 01.) 
